\title{
Knowledge of the Corporate Social Responsibility Concept as a Part of the Intellectual Capital of Small and Medium-sized Organizations from the Perspective of Lifelong Learning
}

\author{
Dana Bernardová ${ }^{1}$, Martin Fink ${ }^{2 *}$, Tetiana Arkhangelska ${ }^{3}$ \\ 1,2,3 Moravian Business College Olomouc, Department of Social Science and Law, Czech Republic \\ *martin.fink@mvso.cz
}

Article History: Received: 10 November 2020; Revised 12 January 2021; Accepted: 27 January 2021; Published online: 5 April 2021

\begin{abstract}
The concept of corporate social responsibility (CSR) can be understood as a part of the intellectual capital (IC) of organizations, as a set of tacit knowledge of CSR holders transferred into the form of explicit knowledge recorded in the documents of organizations. The aim of this study, in terms of lifelong learning, is to determine whether CSR is a part of the IC, whether the knowledge of the CSR concept is of a tacit or explicit nature and to what extent the potential of such knowledge is used by small and medium-sized organizations (SMEs). The presented data are a selection taken from 3 studies carried out by the authors in 2014-2019. The study was conducted in the Olomouc region, SMEs were the respondents, and the content of the study referred to CSR. The data show that a tacit form of knowledge of the CSR concept prevails.
\end{abstract}

\section{Keywords}

CSR, SMEs, intellectual capital, knowledge, lifelong learning

\section{Introduction}

Nowadays, an ethical approach to the entrepreneurship, commonly named as Corporate Social Responsibility (CSR), is a part of global continuous sustainability declared by the UN in the development objectives for the period of 2015-2030. CSR is tightly related to the issues of economics, management, ecology, human resources management, legal issues, public interest, and business ethics [1]. Theoretically, there is a divergence between the internal scope of CSR that concerns dealing with employees in enterprises in the form of investments in developing human resources, health and safety at work, change management, environmental impact management and the external scope of CSR that in turn focuses on the organizational environment, specific region, suppliers and consumers, business partners, as well as human rights and global environmental issues $[2,3]$. When considering Corporate Social Responsibility as a process going on within the environment of specific organizations, it is applied in the following way: values of the individuals - ethical reflection - managerial decisions - specific activities - organizations' success [4].

Therefore, the individual and human factor are the basis for implementation of the CSR concept and success of the whole organization. Its position on the market and profit are the result of the process. CSR - the concept of the ethical approach to business is a part of the intangible capital - the intellectual capital (IC) ${ }^{1}$ in the form of knowledge that can be used to

\footnotetext{
${ }^{1}$ Intellectual capital, which is one of the components of the organization's intangible capital, can be understood as the difference between the market and book value of the organization. The IC forms an interconnection of the human capital as the holder of the so-called tacit knowledge and the organizational capital, or structural capital, the so-called explicit knowledge (these are the mechanisms and processes supporting the explicitly formed knowledge). Social capital in the form of internal interaction and communication in an organization transferring tacit and explicit knowledge then completes the IC as a functional unit. Relational or customer capital is a part of the IC
} 
create value - a sustainable value according to current requirements. The holder of the IC in the form of knowledge is the human capital (individuals) ${ }^{2}$. Consequently, the success of the organization lies in the connection between the human capital and organizational capital (organization management tools) ${ }^{3}$ [9]. Bueno et al. [10] and Ospina [7] consider the IC to be the total of explicit and tacit knowledge. The IC in the field of CSR constitutes of the interconnection between the human capital as the holder of the so-called tacit knowledge about CSR and the organizational capital, the so-called explicit knowledge, recorded in the documents of the organization.

There is a consensus on the assumption that the human capital is the most important part of the IC. It is capable of changing and learning, as a result affecting the other components of the IC to the greatest extent. The development of other parts of the intellectual capital without the appropriate human capital is considerably limited [11]. This idea is also supported by the fact that in a highly competitive environment of the global market, knowledge that is not normally available or is often related only to its holders has become more important. The use of knowledge increasingly differentiates the results of the successful businesses from their competitors. Therefore, the tacit knowledge contained in the potential and capabilities of the human factor is of particular importance. The development of the human factor potential is of the same particular importance.

The strategy as the certain knowledge and procedures incorporating the mission, i.e. visions, objectives, and philosophy, which are intended to meet the main objectives of the organization [8], is a part of the organizational capital as formalised explicit knowledge and intangible assets that are generally owned by the organization. When developing the strategy, it should be remembered that "if the company wants to be successful in the long-term, it must take care not only of generating maximum profit today, but also of satisfying internal and external current and future customers as well as implementing the efficient organization of internal production and management processes and improvement of the qualifications of its employees" [8]. Thus, the IC plays an increasingly important role in creating sustainable development of the organization [12]. The ability to identify the intellectual capital, record it, and evaluate it, and as a result the ability to further develop it becomes a significant competitive advantage. $[9,13,14]$.

Small and medium-sized enterprises (SMEs) represent the majority of economically active entities in Europe and form the basis of Europe's economy by representing more than $95 \%$ of the total number of companies [15]. They are the most dynamically developing companies. 23 million of SMEs generated EUR 3.9 billion in added value and employed 90 million people in 2015 (Annual Report on European SMEs, 2015/2016). SMEs play an important role in the development of the endogenous potential of individual regions of the Czech Republic as they constitute the basis for the regional business [16]. Large organizations comprise only $0.2 \%$ of the total number of companies in the Czech Republic [17]. They are involved in the development of regions only to a lesser extent; however, they still achieve benefits that are neither necessary nor needed in the region [18]. On the other hand, if small businesses do not want to be unemployed, they do business with the so-called economic forcing. The failure of small organizations and consequently their non-engagement in the CSR is due to their reluctance to voluntarily fulfil obligations beyond the necessary scope of their activities [18]. Activities which are not directly related to the subject-matter of entrepreneurship as well as the legislative requirements of the state are burdensome for SMEs. SMEs have some specific features and, according to Enderle in Dalíková [19], they must daily struggle for survival and, as a result, the availability of time and resources that they can invest in the CSR area is limited. Therefore, we are focused on the SMEs segment.

CSR, perceived as the value framework of SME's entrepreneurship and the motivation

according to some concepts - a sum of contacts and relations with customers, partners, suppliers, owners, and investors mainly in the ethical form (according to Karl Erik Sveiby).

${ }^{2}$ From the IC perspective, "human capital represents the human factor in an organization; it is the combination of intelligence, skills, and experience that gives the organization its special character. Employees are capable of learning, change, innovation, and creative efforts and if properly motivated, they ensure the long-term survival of the organization." [5]

${ }^{3}$ Organizational capital can be understood as a structure that an organization creates to support its employees and as the basis for all their activities [6]. It provides the tools for its development. Organizational capital can be defined as the knowledge that the organization formulates, systematizes, and internalizes [7]. It includes internal procedures, communication channels, and a whole structure that enables efficient and effective knowledge management and sharing [8]. 
to do more than just basic business, represents the tacit knowledge in SMEs. CSR, as a part of the organization strategy, organization management tools, implementation, monitoring, reporting, and measurement of CSR in the organization represents the explicit knowledge in SMEs. It is clear that samely as evaluating the IC, it is necessary to also measure the CSRrelated activities in SMEs and to monitor in which form of the IC knowledge (tacit or explicit) is represented.

The aim of this study is to determine whether CSR is a part of the IC, whether the knowledge of the CSR concept is of a tacit or explicit nature and to what extent the potential of such knowledge is used in SMEs.

The research questions are:

1. What is the level of knowledge of the CSR concept in SMEs? Which its form prevails?

2. What motivates SMEs to implement the CSR activities?

3. Is the IC related to the CSR concept used sufficiently?

\section{Methods}

The presented data are a selection of 3 studies carried out by the authors ${ }^{4}$ in 2014-2019.

The research activities have been realized within the common territory (the Olomouc region) including respondents from the region (SMEs), and content (CSR). Although this is not a representative study, the found data sufficiently illustrate the issue under examination.

Research No. 1 (2014): An electronic questionnaire survey called Focus on Small and Medium-Sized Enterprises or Corporate Social Responsibility in the Olomouc Region (351 respondents) was carried out.

Research No. 2 (2015-2018): A questionnaire survey was carried out by the MVSO students within the framework of the CSR project teaching ${ }^{5}$ (81 respondents).

Research No. 3 (2019): In the pre-research process (from January to February 2019) non-standardized interviews for 75-profit and 75 non-profit organizations of SME type in the Olomouc region in order to identify the differences between the two types of organizations according to the questionnaire part of the CSR methodology ETA index $2019^{6}$ were conducted.

\section{Research No. 1:}

\section{Results and findings}

The SMEs in the Olomouc region were asked: 1) whether they know the CSR concept 2) whether they should support socially beneficial activities, 3) whether they respect any principles that go beyond their legal obligations in implementing business, see figure1.

Although only $23.7 \%$ of respondents report on knowing the concept of Corporate Social Responsibility (CSR), the vast majority (92.1\%) fulfils the concept naturally. $47.2 \%$ of the SMEs systematically deal with social responsibility. The majority of respondents $(79.8 \%)$ think that micro, small, and medium-sized enterprises should support socially beneficial activities and more than three quarters of firms (76.76\%), involved in the research, respect some principles that go beyond their legal obligations.

\footnotetext{
${ }^{4}$ The authors carry out the study in the environment of MVSO in the Olomouc region. Moravian Business College Olomouc (MVSO) is a private higher education institution founded in 2005. CSR is one of the key

areas in both science and education. MVSO is located in the regional capital of Olomouc, in the central part of one of the regions of the Czech Republic. The Olomouc region is situated in the central part of Moravia and extends to its northern part. Its area ranks among the smaller regions, occupying the eighth place among 14 regions in the Czech Republic. The Olomouc region is the sixth most populated region in the Czech Republic. The region's economy is focused on traditional agriculture, manufacturing, and services. The strategically advantageous location, transport accessibility, well developed infrastructure, sufficiently skilled workforce, and the entry of foreign investors are the preconditions for the further development of the region.

${ }^{5}$ The MVSO students receive formal education and within the theoretical school preparation they also process their own CSR activity proposals for SMEs in the form of written projects. Subsequently, the students (in the form of non-formal education) carry out the selected projects in teams in cooperation with SMEs from the Olomouc region. The students and cooperating SMEs fill in an electronic questionnaire (as a form of learning evaluation) after implementing the project. The statistical processing of data via online application SurveyMonkey is the method of data collection and analysis. The results are arranged in linear time series [20]. The time series show the process from the past to the present and can capture developing trends. This research includes the period of four years (2015 to 2018), with a total of 81 respondents (2015 - 21; 2016 - 18; 2017 - 21; 2018 - 22). For more information see EMI 2019.

${ }^{6}$ Creation and testing of the CSR Index methodology by the MVSO staff was implemented within the TAČR project No. TL02000336 and was published see [21].
} 
The data show that the knowledge of CSR in SMEs as a part of the IC prevails in the tacit form.

The development of knowledge of the CSR concept was also traced in the following period, see figure 2. MVSO students cooperate with SMEs in implementing CSR projects within the CSR project education. The following evaluation of the CSR project education is approached as a questionnaire survey, which asks both students and representatives of SMEs about the knowledge of the CSR concept. The figure 2 shows the results found out during the four years of evaluation of the CSR project education.

The figure 2 shows that the students' knowledge of the CSR concept reaches higher values than that of the SMEs partners which is most likely due to current knowledge of the concept of students from school education. On the part of the SMEs partners, there is a recurrent strong unfamiliarity with the CSR concept before the CSR project implementation with students. Students are able to identify the principles of CSR in the given organization and in an informal way teach it about using the CSR concept.

The data show that the knowledge of CSR in SMEs as a part of the IC prevails in the tacit form.

Research No. 2:

After the knowledge of the CSR concept in SMEs is established, the next logical step in the research is the question of the motivation of SMEs to implement the CSR activities, see figure 3. The figure 3 shows the results found out during the four years of evaluation of the CSR projects teaching at MVSO. Respondents' responses show that the prevailing motive is the visibility of the enterprise and the effort to do good. The surprising fact is that the least mentioned motive is profit. This fact clearly shows that the tacit form of CSR knowledge prevails in SMEs.

Research No. 3:

Figure 4, which follows the structure (sustainability strategy, economic part, social area, environmental area) of the ETA Index CSR 2019 or SREI (Social Responsibility Eta index), shows the scope for improving the CSR area in the organizations in all the monitored segments. This is also related to education in the same area.

According to the findings, the reporting segment, certification, and CSR policies have the greatest potential for improvement. A relatively little potential for improvement has been identified in the management sector, marketing, and environmental policy.

It can be argued that the potential of the IC represented by the CSR issue is not being used as it could be.

Due to the size of the potential for further development in the field of CSR reporting, certification, and CSR policy, it can be argued that the largest reserves are in the explicit form of CSR knowledge in SMEs.

There is a space to turn the tacit knowledge, contained in the ability to cooperate with the region, in the ethical relation to customers and suppliers into the explicit knowledge contained in reporting, CSR policy, and formulation of values. 
Figure 1. CSR in the Olomouc region

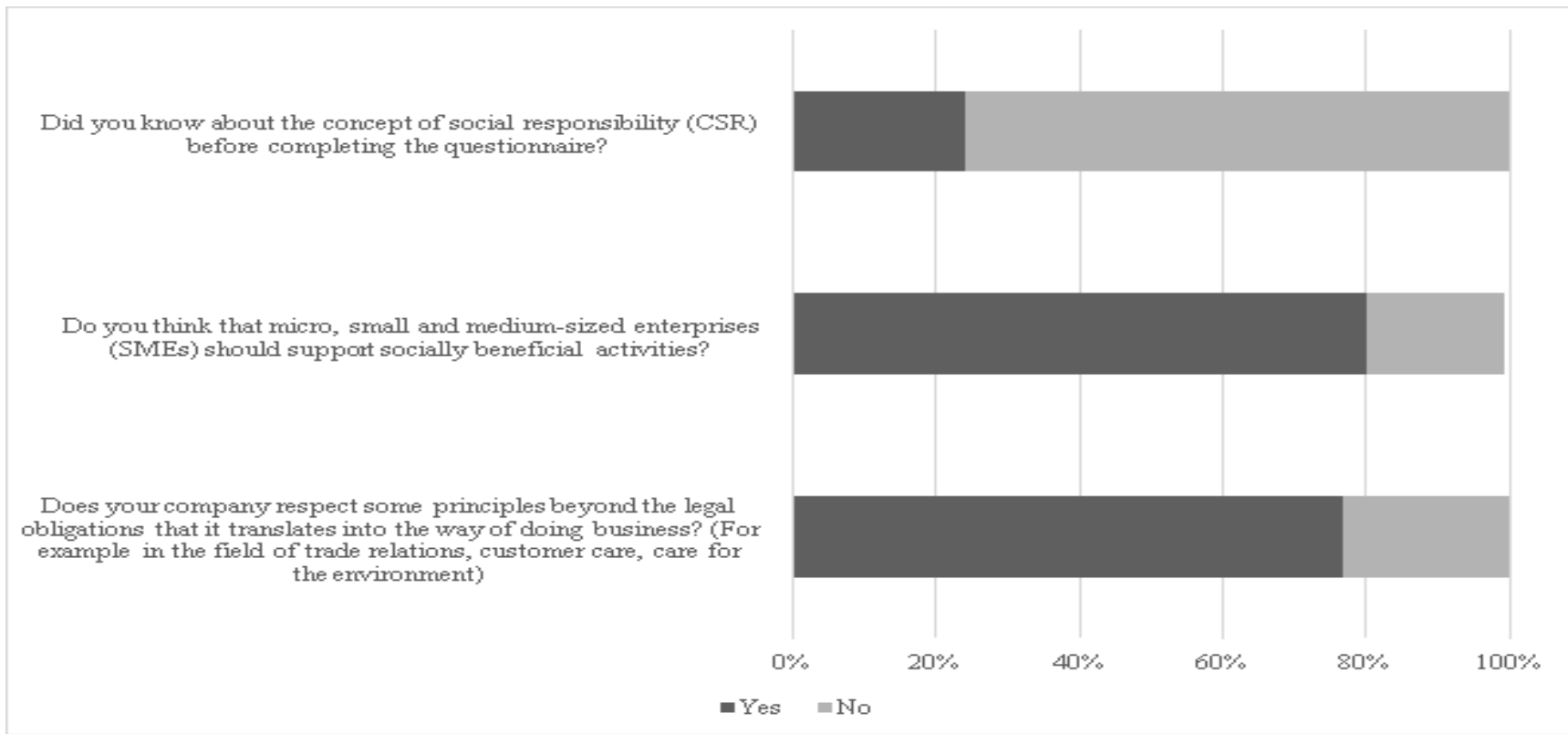

Figure 2. Knowledge of the CSR concept

Corporate partners(2015)

Students (2015)

Corporate partners(2016)

Students (2016)

Corporate partners(2017)

Students (2017)

Corporate partners(2018)

Students (2018)
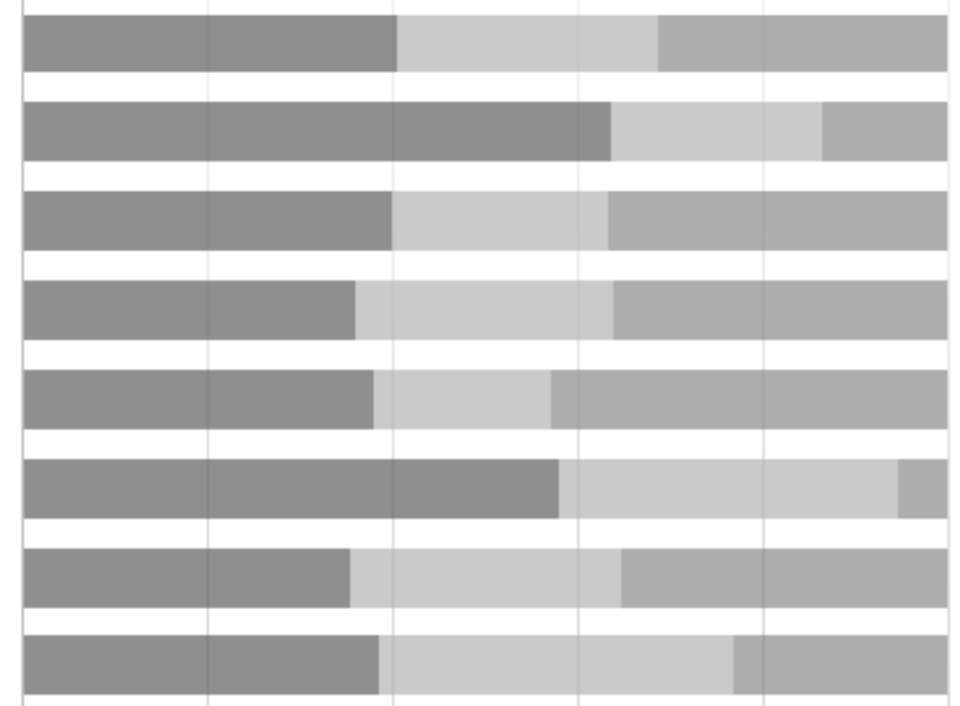

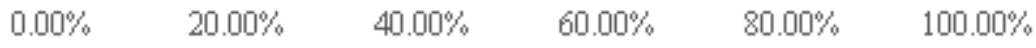

-Did not know neither the idea nor the concept of CSR before implementing the project

Are aware of the idea of the responsible approach but have not heard of the concept

- Know the CSR concept 
Figure 3. Motivation for implementing the CSR activities

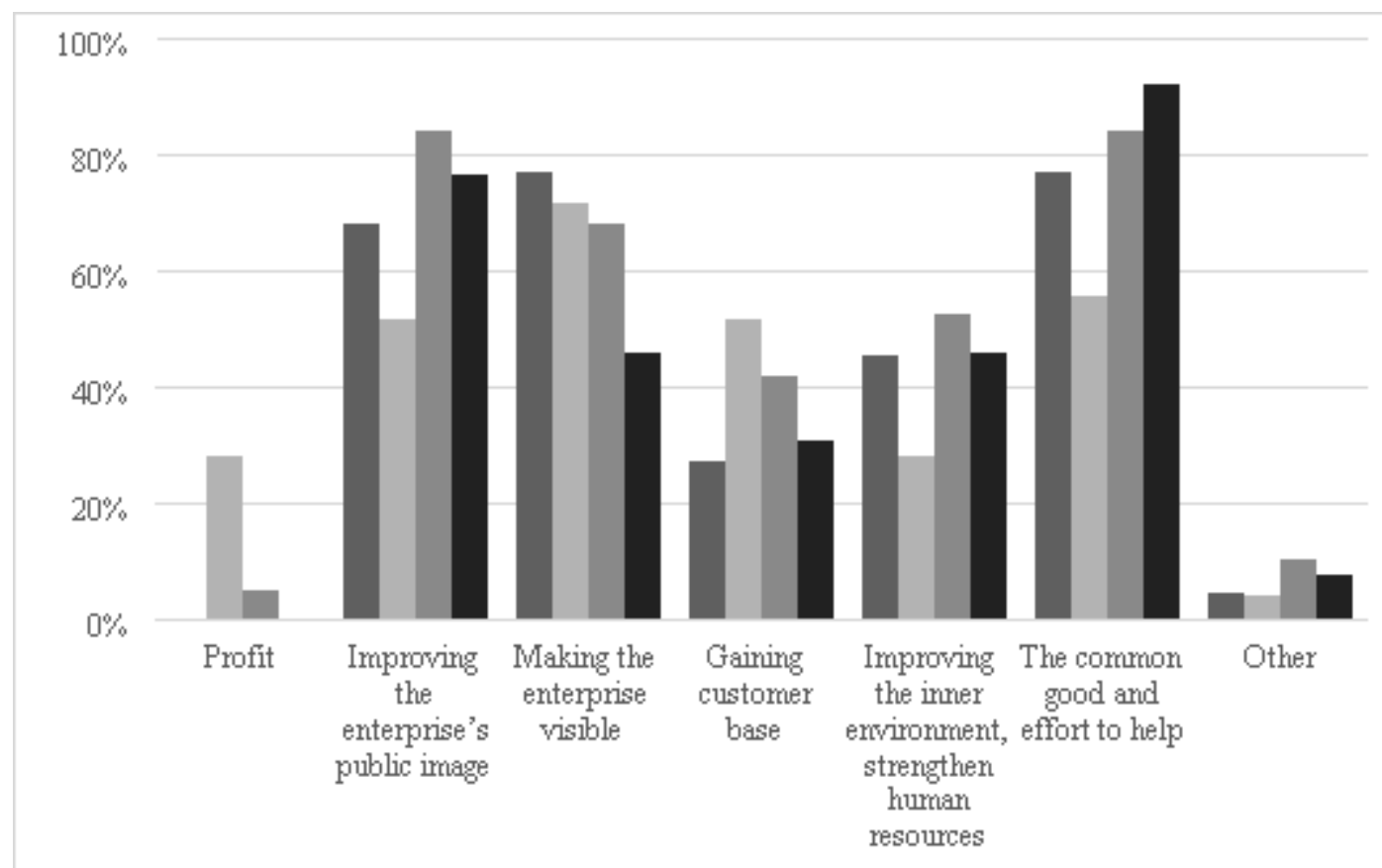

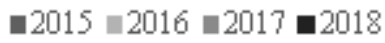

Figure 4. Percentage gains in each CSR area

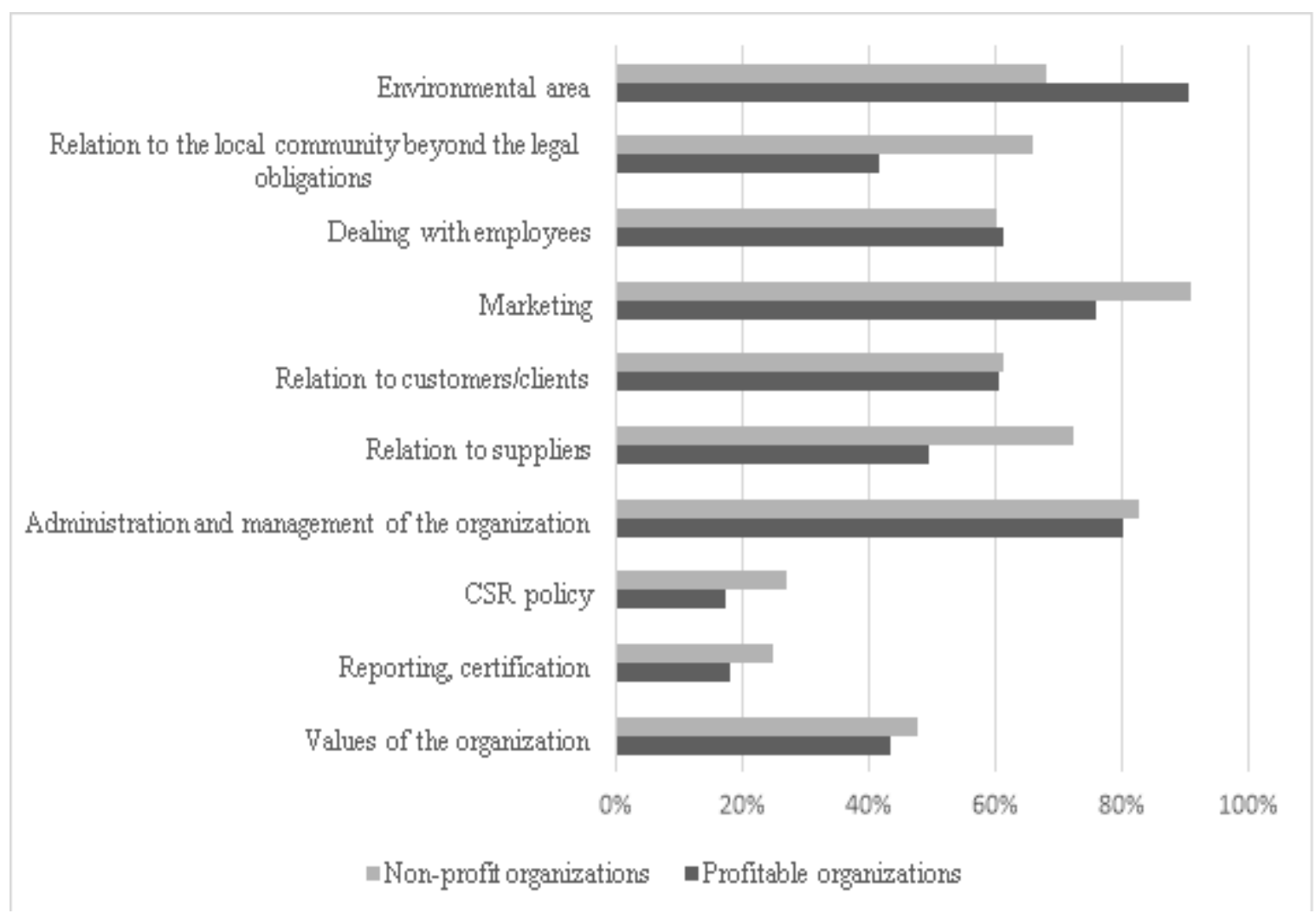

\section{Discussions}

The CSR activities must be seen as an investment, so they must ultimately make a profit 
in the current highly competitive environment [22]. The concept of CSR as a natural need to do good is highly ethical and socially agreeable, but insufficient to strengthen the market position. At the same time, a well thought out link between the responsible approach and organisation's strategy is the subject of the current concept of the CSR concept ${ }^{7}$.

The volume of tacit and explicit knowledge of the CSR concept in SMEs of the Olomouc region shows the underused potential for SMEs for achieving higher profits. It is obvious that one way to achieve better economic results and sustainability in SMEs is to turn the tacit knowledge into explicit knowledge. Solution lies in educating entrepreneurs and managers of SMEs not only in the CSR issue, but also in the issue of internal procedures, communication tools and channels, and the whole structure of the tools for managing organizations that are subject to the organisational capital, i.e. the holder of the explicit knowledge in the organization.

Two forms of an interconnection between the CSR concept and lifelong learning can be seen according to [4].

According to the first form, CSR is a natural part of the moral values of each person which they learn in the process of education (in its broader sense). This form of learning was also reflected in the results of the presented research. SMEs implement the CSR activities explaining it by the effort to do good even though they do not know the CSR concept. According to the second form, CSR is a part of contemporary life, and citizens in their personal life or as employees of different organizations, as well target groups of managers and entrepreneurs must learn (in its narrow sense) to understand and apply it in practice. It is necessary for SMEs to deliberately support the intentional learning process. The process of lifelong learning (LLL) of employees, managers, and entrepreneurs in SMEs plays an important role. This process can be focused on the method of deliberately organized education, i.e. on purpose-built educational events as well as incidental learning from unintentional and random situations as part of the other activities. Incidental learning occurs mainly in practice during the performance of work activities. It can be more effective than intentional learning aimed at CSR educational objectives and can certainly be used in educational practice by choosing optimal methods for education.

In order for the IC to be properly controlled, it must also be measured. The methodology of the CSR indices is used to measure CSR [25]. One of the ways to measure knowledge and activities related to CSR and to educate the employees in the organization at the same time is to use the CSR ETA Index 2019 methodology, which is being prepared by the team of MVSO experts since 2017, currently within the TACR project. It is a tool not only for indexing all types of organizations, but also for educating and developing the intellectual capital in the field of CSR. It is a self-awareness mechanism setting the CSR index in a simple numerical value according to the achieved points. The questionnaire was prepared based on the standardized valid CSR questionnaire from the European, GRI methodology, ISO 26000 , world professional literature study and the expert conference [21]. It provides an overview of all the areas, topics, and activities of CSR that organizations can and should implement with a weight assessment of these areas so that it can show the significance of each of the included item in the CSR concept. The repeated use of the CSR index and the possibility of having an insight into the CSR index of other similar organizations result in educating according to the constructivist method of E-A-R learning [26].

\section{Conclusion}

The aim of this paper is to determine whether CSR is a part of the IC in SMEs and in what specific form (tacit or explicit knowledge) it prevails. The data show that SMEs work with the CSR concept applying it in the way of conducting business. The knowledge of CSR in SMEs prevails in the tacit form. SMEs implement socially responsible activities and realize the need for the ethical approach to the surrounding society while not always

\footnotetext{
${ }^{7}$ The UN states that: "Corporate sustainability is imperative for business today-essential to long-term corporate success and ensuring that markets deliver value across society. To be sustainable, companies must do five things: Foremost, they must operate responsibly in alignment with the universal principles and take actions that support the society around them. Then, to push sustainability deep into the corporate DNA, companies must commit at the highest level, report annually on their efforts, and engage locally where they have presence." [23] The definition by Rasche et al., [24] says: "CSR policy acts as a self-regulatory mechanism by which the company monitors and ensures its active compliance with the legal spirit, ethical standards, and national or international standards."
} 
managing to name this approach as CSR.

The motivation for CSR lies in the visibility of the enterprise and the effort to do good, not in profit. SMEs do not sufficiently benefit from the CSR activities and as a result their competitive advantage on the market is underused.

The IC related to the CSR concept in SMEs has not been sufficiently used yet. It is a significant part of the human capital (in the form of tacit knowledge) and is insufficiently contained in the organizational capital in the form of explicit knowledge.

The LLL strategy focused on SMEs should develop the IC of the learning persons in balance between the explicit knowledge and tacit knowledge. It should effectively and sensitively link intentional and incidental learning, including the possibility of making use of the learning person's own experience. The interconnection of intentional and incidental learning within the E-A-R methodology which the CSR index is purposely based on for CSR measurement and at the same time for education in CSR - ETA Index CSR 2019 is of particular importance in SMEs considering their specifics of entrepreneurship.

\section{Acknowledgement}

This article is dedicated to the Project No. TL02000336: Corporate Social Responsibility Index under the Éta 2 TAČR Program financed by the Technology Agency of the Czech Republic.

\section{References (APA 6 ${ }^{\text {th }}$ edition)}

[1] Garriga, E., \& Méle, D. (2004). Corporate Social Responsibility Theories: Mapping the Territory. Journal of Business Ethics. 53(1-2), 51-71.

[2] Den Hond, F., De Bakker, F. G. A., \& Neergaard, P. (2007). Managing Corporate Social Responsibility in Action: Talking, Doing and Measuring. Hampshire: Ashgate Publishing.

[3] Pavlík, M. \& Bělčík, M. (2010). Společenská odpovědnost organizace: CSR v praxi a jak s ním dál [Corporate Social Responsibility: CSR in Practice and How to Deal with It Then] Praha: Grada

[4] Pokorná, D. (2012). Koncept společenské odpovědosti: obsah, podstata, rozsah [Concept of Social Responsibility: Content, Basis, Scope]. Olomouc: Univerzita Palackého.

[5] Koubek, J. (2009). Několik poznámek k pojetí lidského kapitálu [A few notes on the concept of human capital]. In: Sborník konference RELIK 2009 [Proceedings of the konference RELIK 2009]. Praha: VŠE

[6] Luthy, D.H. (1998). Intellectual Capital and Its Measurement. Logan, Utah: College of Business Utah State University

[7] Ospina, D. E. R. (2007). Capital intellectual. Algunas reflexiones sobre su importancia en las organizaciones. Pensamiento y gestion. 23, 131-152.

[8] Truneček, J. (2003). Znalostní podnik ve znalostní společnosti [Knowledge enterprise in a knowledge society]. Praha: Professional publishing.

[9] Bontis, N., Dragonetti, N, C., Jacobsen, K., \& Roos, G. (1999). The knowledge toolbox:: A review of the tools available to measure and manage intangible resources. European Management Journal. 17(4), 391402.

[10] Bueno, E., Morcillo, P., \& Rodríguez, J. (2002). Intellectual capital and Scientific-Production of the Madrid Research Centres. Proceedings of the International Conference "The Transparence Enterprise. The Value of Intangibles". Madrid.

[11] Hemmati, H., \& Zamani, R. (2012). The relationship between intellectual capital and value added and cumulative abnormal returns. Journal of industrial strategic management. 8(24), 44-58.

[12] Kaplan, R.S., \& Norton, D. P. (2010). Efektivni systém řizení strategie. Nový nástroj zvyšování výkonnosti a vytváření konkurenční výhody [The Execution Premium: Linking Strategy to Operations for Competitive Advantage]. Praha: Management press.

[13] Stewart, T.A. (1997). Intellectual capital: The New Wealth of Organizations. New York: Doubleday/ currency.

[14] Kang,S. C., \& Snell, S.A. (2009). Intellectual Capital Architectures and Ambidextrous Learning: A Framework for Human Resource Management. Journal of Management Studies.46(1),65-92. https://onlinelibrary.wiley.com/ doi/abs/10.1111/j.1467-6486.2008.00776.x

[15] Edinburgh group (2012). Growing the global economy through SMEs.

[16] Ministry of Industry and Trade of the Czech Republic (2013). The concept of support of SMEs 2014-2020.

[17] Válová, A., \& Formánková, S. (2014). Corporate Philanthropy in the Czech Republic. Procedia Economics and Finance, 12, 725-732. doi: 10.1016/S2212-5671(14)00399-2. 
[18] Vojík, V. (2010). Specifika podnikání malých a středních podnikatelů v tuzemsku i v zahraniči [Specifics of Business of Small and Medium-Sized Enterpreneurs in the Country and Abroad]. Praha: Wolters Kluwer

[19] Dalíková, P. (2015). Social responsibility in the management and economy of business entities. České Budějovice: University of South Bohemia in České Budějovice, Faculty of Economics, Department of Management.

[20] Horák, J., Litschmannová, M., Inspektor, T., Vojtek, D., \& Fojtík, D. (2017). Průzkumová analýza dat se zaměrením na GIS statistiku [Exploratory Data Analysis with a Focus on GIS Statistics]. Ostrava: VŠB Technická univerzita Ostrava.

[21] Fink, M., Ivanová, K., Bernardová, D., Arkhangelska, T., \& Kašparová, K. (2020). Social Responsibility ETA Index 2019. International Journal of Curriculum and Instruction. 12 (Special Issue), 50-65. Retrieved February18, 2020, from https://files.eric.ed.gov/fulltext/EJ1245281.pdf

[22] Friedman, M. (1970). The Social Responsibility of Business is to Increase Its Profits. The New York Times Magazine.

[23] United Nations (2014). United Nations Global Compact. UN. Retrieved March 24, 2019, from https://www.globalcompact.de/ wAssets/docs/Nachhaltigkeits-CSRManagement/un_global_compact_guide_to_corporate_sustainability.pdf

[24] Rasche, A., Morsing, M., \& Moon, J. (eds.). (2017). Corporate Social Responsibility: Strategy, Communication, Governance. Cambridge: Cambridge University Press.

[25] Kašparová, K., \& Kunz, V. (2013). Moderní př́stupy ke společenské odpovědnosti firem a CSR reportování [Modern Approaches to Corporate Social Responsibility and CSR Reporting]. Praha: Grada.

[26] Košt'álová, H., \& Hausenblas, O. (2001). Co je E-U-R. In: Kritické Listy. Retrieved March 22, 2020, from ttp://www.kritickemysleni.cz/

klisty.php?co=klisty24_eur 